\title{
Jakościowa analiza porównawcza (QCA) jako nowa metoda badawcza w nauce o polityce: zarys zagadnienia
} Qualitative Comparative Analysis (QCA)
as the new research method in political science:
an outline of the issue

Stowa kluczowe: studium przypadku, metoda badawcza, dane jakościowe, analiza polityczna

Keywords: case study, research method, qualitative data, political analysis

Abstrakt: Artykut przedstawia główne założenia teoretyczne $i$ aspekty empiryczne stosowania jakościowej analizy porównawczej (QCA). Opisuje podstawowe etapy zastosowania tej metody badawczej jako alternatywy dla podejścia ilościowego $w$ nauce o polityce. Wskazuje na zalety $i$ wady tej metody badawczej z punktu widzenia wartości poznawczej wyników, które uzyskuje badacz dzięki jej zastosowaniu. Wskazano także polskie $i$ zagraniczne przykłady jej implementacji $w$ procesie badawczym.

Abstract: The article presents main theoretical assumptions and empirical implementations of Qualitative Comparative Analysis (QCA). The main phases of this research method, as the alternative to the quantitative approach which is applied in political science are described. Strengths and weaknesses of this method are described from the perspective of epistemological value obtained by the user of QCA method. Some Polish and foreign examples of QCA implementation are also indicated.

* ORCID ID: https://orcid.org/0000-0001-8167-6747, pracownik naukowo-dydaktyczny na Wydziale Nauk Politycznych i Studiów Międzynarodowych Uniwersytetu Warszawskiego. E-mail: p.potocki2@uw.edu.pl

** ORCID ID: https://orcid.org/0000-0002-4247-228X, pracuje w CBM Indicator. E-mail: iw.lassota@student.uw.edu.pl 


\section{Wprowadzenie}

Badania społeczne są ważnym narzędziem służącym poznaniu, zrozumieniu, a także wyjaśnieniu postaw i zachowań grup społecznych oraz zbiorowości. Jak wyjaśnia E. Babbie: „badania społeczne polegaja na systematycznej obserwacji życia społecznego $w$ celu odkrycia $i$ zrozumienia prawidłowości, które wykazuje przedmiot obserwacji” ${ }^{1}$. Aby jednak właściwie zbadać dane zjawisko lub problem trzeba odpowiednio dobrać narzędzia badawcze i metodologie. Badania społeczne dzielą się na badania ilościowe i jakościowe. Jakościowa analiza porównawcza (ang. Qualitative Comparative Analysis, dalej jako QCA) jest stosunkowo nowym podejściem metodologicznym w naukach społecznych, które zaczęło rozwijać się dzięki opublikowaniu przez amerykańskiego socjologa Charlesa C. Ragina książki The comparative method: Moving beyond qualitative and quantitative strategies” w 1987 r. ${ }^{2}$ Sam autor wskazywał, że jego książka miała połączyć podejście ilościowe (ang. variable-oriented) z podejściem jakościowym (ang. case-oriented) poprzez zastosowanie metody porównawczej, aby zachować integralny charakter jednostki analizy i odnosić się do konfiguracji cech tych jednostek. Model wyjaśniający miał powstawać stopniowo, ukazać różne zależności przyczynowe prowadzące do tych samych wyników, a także regulować zakres złożoności analizy empirycznej ${ }^{3}$. Zgodnie z danymi zawartymi w serwisie internetowym Google Scholar ta książka od 1991 do 2020 r. (stan na lipiec) była zacytowana 10442 razy. To imponujący wynik pokazujący bardzo duże znaczenie tego badacza dla kształtowania samoświadomości metodologicznej naukowców na całym świecie $e^{4}$. Stosowanie QCA stało się wręcz pewną swoista „modą metodologiczną”, która rozpoczęła się wraz z końcem lat 90. ub. wieku, gdy badacze zaczęli w coraz większym stopniu przejawiać zainteresowanie wieloaspektową analizą przypadków (ang. case), która miała na celu uchwycenie złożoności zjawisk społecznych przy jednoczesnym zachowaniu ambicji zmierzających do tworzenia generalizacji ${ }^{5}$. Istotnym czyn-

1 E. Babbie, Podstawy badań społecznych, Warszawa 2013, s. 17.

2 G.C. Ragin, The comparative method: Moving beyond qualitative and quantitative strategies, Berkeley 1987.

3 A. Marx, B. Rihoux, C. Ragin, The origins, development, and application of Qualitative Comparative Analysis: the first 25 years, «European Political Science Review» 2014, vol. 6, s. $119-120$.

4 Zob. https://scholar.google.com (28.07.2020).

5 A. Marx, B. Rihoux i C. Ragin, The origins, development, and application of Qualitative Comparative Analysis..., s. 129. 
nikiem, który przyczynił się do wzrostu popularności QCA jako nowej metody badawczej był fakt, że nauki społeczne doświadczyły swoistej rewolucji informatycznej pod koniec lat 90. ub. wieku, gdy oprogramowanie umożliwiające stosowanie QCA stało się coraz bardziej dostępne. W świadomości metodologicznej polskich badaczy procesów i zjawisk politycznych QCA jako nowa metoda badawcza, jest rzadko obecna ${ }^{6}$. To wskazuje, iz istnieje luka poznawcza dotycząca możliwości wykorzystania QCA przez polskich politologów. Podstawowym celem tego artykułu jest zatem ukazanie potencjału teoretyczno-empirycznego tej metody. Szczegóły dotyczące jej stosowania zostaną omówione przede wszystkim przez pryzmat zaimplementowania QCA w ramach programu komputerowego fs/QCA. Całość rozważań będzie osadzona w kontekście swoistości epistemologicznej ilościowych i jakościowych metod badawczych, dla których QCA ma stanowić swoisty pomost umożliwiający wykorzystanie silnych stron analizy ilościowych i jakościowych danych empirycznych. Zostaną także wskazane przykłady zastosowania tej metody badawczej w Polsce i na świecie (tabela 1) oraz przedstawione wybrane argumenty badaczy odnoszących się krytycznie do możliwości eksplanacyjnych tej metody badawczej.

Dla umieszczenia QCA w odpowiednim kontekście metodologicznym konieczne jest przypomnienie podstawowych różnic między badaniami ilościowymi i jakościowymi. Dotyczą one: pytań badawczych, celu badania, możliwości zastosowania, wielkości próby badawczej, sposobu pomiaru danych empirycznych, roli uczestnika badania, roli badacza, charakterystyki uzyskanych wyników badania ${ }^{7}$. Badanie jakościowe służy uzyskaniu wiedzy na temat złożoności strukturalno-funkcjonalnej określonego fragmentu rzeczywistości społecznej w aspekcie subiektywnym. Natomiast badanie ilościowe opiera się na założeniu, że badacz przy pomocy określonych działań agregujących i porządkujących uzyskane dane empiryczne może dokonać opisu i wyjaśnienia złożoności procesów i zjawisk społecznych w aspekcie obiektywnym, czyli pozwalającym na stworzenie generalizacji wykraczających poza określony terminem i miejscem badania kontekst czasowo-przestrzenny. Wspólnym mianow-

6 Jest to metoda pozwalająca poddać analizie w nowym kontekście teoretycznym już istniejące dane empiryczne, co stanowi potencjalnie wartościowe heurystycznie uzupełnienie strategii problemowej dotyczącej analizy procesów i zjawisk politycznych. Por. T. Klementewicz, Metateoretyczne dylematy politologa $-w$ poszukiwaniu strategii badania, «Studia Politologiczne» 2009, vol. 14, s. 29-30.

7 P. Tarka, Specyfika i komplementarność badań ilościowych i jakościowych, «Wiadomości Statystyczne» 2017 , vol. 3, s. 21-22. 
nikiem obu tych metod jest porównywanie danych empirycznych, czyli stosowanie komparatystyki. Jest ona definiowana następująco: „metoda naukowa stosowana m.in. w politologii, polegająca na określeniu podobieństw, różnic, analogii, zależności badanych zjawisk. Zaadaptowana na grunt politologii z językoznawstwa, prawa i biologii. Aktualnie bardzo często stosowana przez politologów metoda badawcza. Jej wartość polega na badaniu wieloczynnikowym danych obiektów, zjawisk czy procesów. (...) K. jest metodą polegająca na szukaniu podobieństw i różnic, jednak bez stosowania ocen, co wiąże się z szerokim zastosowaniem metod ilościowych (kwantytatywnych) ${ }^{8}$. Jest to metoda wymagająca zastosowania przez badacza określonych kryteriów selekcji danych empirycznych, które opierają się na jego preferencjach epistemologiczno-ontologicznych. Badacz musi dokonać określonej hierarchizacji problemów badawczych i wybrać ten, który uznaje za najistotniejszy.

Głównym założeniem metodologii badań jakościowych jest traktowanie przedmiotu badania w sposób holistyczny, natomiast przeprowadzania badania polega na porównywaniu przypadków ze sobą. W naukach społecznych do zoperacjonalizowania użycia tej metody używa się terminu typów idealnych opracowanego przez Maxa Webera ${ }^{9}$. Podejście to polega na tworzeniu pewnego idealnego konstruktu mechanizmu, zbiorowości lub struktur, który następnie porównuje się z materiałem badawczym. Samo zobrazowanie wyników badania staje się wówczas bardziej czytelne i łatwiejsze do porównania. Metody jakościowe są używane do identyfikacji niezmiennych relacji i wskazania mechanizmów stałych powiązań, a nie do wyjaśniania zmienności ${ }^{10}$. Jakościowe metody badawcze umożliwiają nie tylko określanie badanych przypadków, ale rozróżnianie rodzajów zjawisk społecznych. Problemem związanym z tym podejściem jest to, że każdy z przypadków jest układem zmiennych, które trzeba traktować jako całość, zwracając uwagę na szczegóły strukturalne i funkcjonalne analizowanego zjawiska.

Metodologia badań ilościowych opiera się na założeniu, że czynniki tworzące dane zjawisko można skwantyfikować jako zmienne zależne i niezależne, natomiast przeprowadzanie badania polega na statystycznej analizie relacji między konfiguracjami czynników. Przed przeprowadza-

8 E. Młyniec, Komparatystyka, [w:] A. Antoszewski, R. Herbut, Leksykon politologii wraz $z$ Aneksem o: reformie samorzadowej, wyborach do sejmu, prezydenckich oraz gabinetach rzadowych, Wrocław 2004, s. 165.

9 Zob. P. Załęski, Typy idealne $w$ socjologii religii Maxa Webera. Analiza struktury kategoryzujacej pole religijne, «Kultura i Społeczeństwo» 2003, vol. 1.

10 B.L. Berg, Qualitative Research Methods for the Social Sciences, Boston 2001. 
niem badań ilościowych stawiane się hipotezy, które potem można przetestować na dużych zbiorowościach, które gwarantują większą istotność i równorzędność wyników ${ }^{11}$. Celem badań ilościowych jest wyjaśnianie zjawisk makrospołecznych, które są pokazywane jako ogół zbieżności danych. Przeprowadzenie badania ilościowego zaczyna się od sformułowania hipotezy, która jest oparta na teorii, potem następuje analiza powiązań między cechami i funkcjami danego zjawiska społecznego, potem hipoteza jest testowana. Później konstruowane są modele i wnioski w oparciu o uzyskane wyniki ${ }^{12}$. Badania ilościowe pozwalają badaczom na dokonywanie rozległych i uogólnionych stwierdzeń o mechanizmach społecznych. Zapewniają porównywanie dużej liczby zmiennych i prowadzą do tego, że możliwe jest konstruowanie alternatywnych wyjaśnień obiektów analizy, w oparciu o te same dane, bez potrzeby przeprowadzana nowego badania. Wadami tej metodologii są jednak potencjalnie zbyt szeroki zakres generalizacji empirycznej, a także pomijanie ważnych kontekstów i aspektów przedmiotu badania. Możliwa jest także zbyt duża abstrakcyjność wyników oraz ograniczenie ich wartości poznawczej, w zależności od zakresu czasowo-przestrzennego uogólnień.

W badaniach porównawczych podstawową kategorią poznawczą jest „przypadek” (ang. case), który jest jednostką obserwacji (pojedynczej lub wielokrotnej) oraz jednostką analizy (o charakterze jednowymiarowym lub wielowymiarowym). Działania badawcze dotyczące danego przypadku są podejmowane $\mathrm{w}$ ramach studium przypadku ${ }^{13}$, które jest intensywnym procesem poznawania danego przypadku w celu poznania większej grupy przypadków określonego rodzaju ${ }^{14}$. Ten proces może być realizowany przy zastosowaniu różnych kryteriów selekcyjnych jednostki obserwacji/ analizy oraz stopnia ich złożoności. W literaturze przedmiotu wskazuje się m.in. na następujące metody wyboru przypadku do analizy: typowość, zmienność, wartości nietypowe, wartości odstające, oddziaływanie zmiennych niezależnych, kluczowy charakter, wyróżniająca się zależność przy-

11 Ch. Frankfort-Nachmias, D. Nachmias, Metody badawcze w naukach społecznych, Poznań 2001.

12 Por. M. Wajzer, Modele matematyczne w politologii - podstawy teoretyczne i przykłady użycia, «Studia Politologiczne» 2019, vol. 53.

13 Polskie przykłady zastosowania studium przypadku zob. A. Dąbrowski, Metoda studium przypadku krok po kroku, «Studia Socjologiczne» 2017, vol. 4, s. 252-253.

14 J. Gerring, The Case Study: What it is and What it Does, [w:] C. Boix, S.C. Stokes (red.), The Oxford Handbook of Comparative Politics, September 2009, doi:10.1093/oxfor dhb/9780199566020.001.0001, s. 95. 
czynowa, wysoki poziom podobieństwa, wysoki poziom zróżnicowania ${ }^{15}$. Wybór kryterium selekcyjnego przez badacza zależy od celu poznawczego całego projektu badawczego. Poziom złożoności analizy wzrasta w sytuacji, gdy badacz zamierza uzyskać dane empiryczne umożliwiające mu szczegółowy opis struktury, funkcji i relacji jednostki analizy z otoczeniem zewnętrznym, które wykraczają poza analizę wyłącznie jednego przypadku - stosuje wówczas procedurę porównań. Wtedy mogą pojawić się problemy dotyczące: większej liczby czynników przyczynowych niż jednostek obserwacji, stworzenia pojęć pozbawionych kontekstu sytuacyjnego, stosowania tendencyjnych kryteriów selekcji, nieuwzględnienia kluczowych zmiennych, błąd ekologizmu i błąd indywidualizmu ${ }^{16}$. Ta lista problemów wskazuje, z jakimi wyzwaniami metodologicznymi musi zmierzyć się badacz, który chce poruszać się w nurcie polityki porównawczej (ang. comparative politics). Arend Lijphart już blisko 50 lat temu wskazywał, że istnieją sposoby przeciwdziałania wyzwaniu dotyczącemu analizowaniu wielu zmiennych w sytuacji, gdy badacz dysponuje małą liczba przypadków - ich wspólnym mianownikiem powinno być dążenie do minimalizacji wystąpienia błędów w procesie interpretacji danych poprzez redukcję liczby analizowanych zmiennych lub zwiększenie liczby analizowanych przypadków ${ }^{17}$.

QCA jest metodą badawczą, która miała stanowić pomost między metodami ilościowymi i jakościowymi ze względu na sposób operacjonalizacji wykorzystania zmiennych w analizie. W podejściu ilościowym zakłada się, że uzyskanie opisu i modelu wyjaśniającego danego zjawiska politycznego jest możliwe poprzez stworzenie zamkniętego zbioru zmiennych niezależnych i tworzenie wiedzy o charakterze ekstensywnym (generalizacje), natomiast w podejściu jakościowym proces wyboru zmiennych do analizy jest otwarty, bo w analizie dołączenie kolejnych zmiennych do modelu powinno skutkować tworzeniem wiedzy o charakterze intensywnym (nowe koncepcje) ${ }^{18}$. Przyczynowość w ujęciu

15 Tenże, 28; Case Selection for Case-Study Analysis: Qualitative and Quantitative Techniques, [w:] J.M. Box-Steffensmeier, H.E. Brady and D. Collier (red.), The Oxford Handbook of Political Methodology, September 2009, doi:10.1093/oxfordhb/9780199286546.001.0001, s. 647.

16 J. Bajer, Badania porównawcze w politologii: zagadnienia metodologiczne, «Studia Politicae Universitatis Silesiensis» 2012, vol. 8, s. 47.

17 A. Lijphart, Comparative Politics and the Comparative Method, «The American Political Science Review» 1971, vol. 65, s. 686-690.

18 C.C. Ragin et al., Complexity, Generality, and Qualitative Comparative Analysis, «Field Methods» 2003, vol. 15, s. 323-324. 
ilościowym jest ujmowana jako relacja deterministyczna, a w podejściu jakościowym jako relacja probabilistyczna. To w procesie badawczym ukierunkowuje się sposób wyboru technik analizy danych i sposoby interpretacji wyników analizy. Oba podejścia dopuszczają wyjaśnianie wieloczynnikowe jako potencjalnie najlepszą drogę do uzyskania modelu wyjaśniania zjawiska przyczynowego, ale tylko w podejściu ilościowym założenie o addytywności oddziaływania zmiennych niezależnych jest wyraźną dyrektywą metodologiczną ${ }^{19}$. Podejście do relacji przyczynowych, które zaproponował C.C. Ragin jest w literaturze przedmiotu wyraźnie określane jako „innowacyjne” (ang. innovative work), ze względu na nowy sposób podejścia do warunków koniecznych i wystarczających relacji przyczynowych, który opiera się na zastosowaniu logiki Boole’a ${ }^{20}$. Dane jakościowe są w procesie analizy obiektem przekształceń o charakterze formalnym, którego efektem mają być wnioski badawcze oparte na podstawie empirycznej.

Jak zatem jest rozumiana i definiowana jakościowa analiza porównawcza w literaturze przedmiotu? Sam jej twórca, C.C. Ragin, twierdzi, że zapewnia ona narzędzia analityczne do przeprowadzenia całościowych porównań przypadków, rozumianych jako konfiguracje czynników, w celu wyjaśnienia wzorów ich podobieństw i różnic ${ }^{21}$. Znalezienie podobieństw w zakresie relacji przyczynowych między poszczególnymi konfiguracjami stanowi punkt końcowy całej analizy w QCA. To zależy od liczby analizowanych przypadków, a więc sytuuje się między studium pojedynczego przypadku i liczbą jednostek analizy umożliwiającą przeprowadzenie wnioskowania statystycznego - są to sytuacje analityczne określane jako „medium-N situations”22. Określenie optymalnej liczby jednostek analizy w przypadku QCA zależy od założeń teoretycznych projektu badawczego i celów badania. Ujmując w sposób syntetyczny istotę QCA można ją zdefiniować następująco: "Jakościowa analiza porównawcza jest porównawczym studium przypadku i zbiorem technik opartych na teorii zbiorów i algebrze Boole’a, która łączy zalety jakościowych i ilościowych

19 S. Nowak, Metodologia badań społecznych, Warszawa 2012, s. 356.

20 H. Kincaid, Causation in the Social Sciences, [w:] H. Beebee, C. Hitchcock, P. Menzies (red.), The Oxford Handbook of Causation, January 2010, doi:10.1093/oxfor dhb/9780199279739.001.0001, s. 736.

21 C.C. Ragin, The Logic of Qualitative Comparative Analysis, «International Review of Social History» 1998, vol. 43, s. 107.

22 B.F. Braumoeller, Guarding Against False Positives in Qualitative Comparative Analysis, «Political Analysis» 2015, vol. 23, s. 471. 
metod badawczych”23. QCA umożliwia detekcję warunków koniecznych i warunków, które są elementami związków przyczynowo-skutkowych, co jest realizowane poprzez redukcję, określonych w ramach teorii ścieżek przyczynowych, do możliwie najprostszej, empirycznie potwierdzonej konfiguracji czynników. To rozumienie zależności empirycznych znajduje się w opozycji do podejścia korelacyjnego, które zakłada występowanie współzmienności wartości dwóch czynników występujących we wszystkich jednostkach analizy.

Formalizując logikę analizy porównawczej C.C. Ragin dostrzegł wiele problemów w dopasowaniu oraz zespoleniu metodologii jakościowej i ilościowej. Głównym dylematem, związanym z konwertowaniem narzędzi badawczych, było ich dostosowanie, tak aby mogły zawierać w sobie analizę jakościową jak i ilościową ${ }^{24}$. W jakościowej analizie porównawczej zmienne zostały zastąpione zestawami danych. Zmienne są wyznacznikiem wymiaru różnorodności danych, natomiast zestaw danych jest kombinacją nastawioną na analizę konkretnego przypadku. Sposoby pomiaru bazujące na ilościowych wskaźnikach, które odzwierciedlają zbiór przypadków, w jakościowej analizie porównawczej zostały zastąpione kalibracjami danych, które zawierają interpretacje wskaźników w stosunku do czynników zewnętrznych. Zmienne zależne, na podstawie których są tworzone i wyjaśniane modele, są zastępowane analizą jakościową ${ }^{25}$. Badacze na początku konceptualizują zjawisko, wyjaśniając je jako wynik odpowiednich procesów, które podczas późniejszych etapów procesu badawczego stają się zmiennymi. Kolejną alternatywą jest stosowanie celowo przygotowanych populacji, zamiast tych dobranych w sposób losowy. Aby zbadać przypadek według QCA należy najpierw dobrać odpowiednie czynniki wpływające na rezultat, a można to zrobić tylko dobierając próbę na podstawie określonych teoretycznych kryteriów. Następną alternatywą jest zastąpienie korelacji, które zawsze są symetryczne (obecność przyczyny lub skutku między dwoma zmiennymi) ustalonym zestawem stosunków, dzięki którym można badać bardziej skomplikowane zależności np. sub-relacje. W konsekwencji macierze korelacji zostały zastąpione tabelami prawdy ${ }^{26}$. Pozwala to na zbadanie,

23 A. Marx, B. Rihoux, C. Ragin, The origins, development, and application of Qualitative Comparative Analysis..., s. 115.

24 C.C. Ragin, D. Zaret, Theory and Method In Comparative Research: Two Strategies, «Social Forces» 1983, vol. 61, s. 731-754.

25 C.C. Ragin, The Comparative Method: Moving Beyond Qualitative and Quantitative Strategies, Oakland 2013, s. 11.

26 Tamże, s. 11. 
jak poszczególne aspekty przypadku łączą się w relacje przyczynowe i jakie są tego konsekwencje eksplanacyjne.

C.C. Ragin opracował jakościową analizę porównawczą na podstawie wcześniejszych prób połączenia różnych rodzajów analiz danych jakościowych. Pierwszą z nich opracowali Shorter i Tilly aplikując analizę statystyczną na dane dotyczące jednego przypadku - strajków we Francji27. Założeniem było zbadanie przekrojowo całego zjawiska w czasie. Celem badań było wówczas odnalezienie „formy” tych procesów. Kolejną próbą połączenia podejścia jakościowego i ilościowego był opis rewolucji agrarnej Paige'a ${ }^{28}$. Naukowiec przeprowadził analizę konceptualizując dany przypadek, który miał ilustrować teorię, jako zmienną skali pomiarowej. Trzecim podejściem była próba opisu przejścia od kapitalizmu do socjalizmu Stephens'a 29 . Analiza polegała na uważnej obserwacji przypadków skrajnych, jako pomocy do identyfikacji ominiętych zmiennych. Stosowano także porównywanie przypadków ze sobą, aby zgłębić formę analizy. Na podstawie obserwacji tych opracowań C.C. Ragin sformułował główne założenia QCA.

Przypadkowość złożoności ${ }^{30}$ pojawia się we wszystkich aspektach życia społecznego. Efekt końcowy danego procesu może być uwarunkowany przez wiele czynników - od pojedynczego wydarzenia, szeregu zjawisk do nieznanych okoliczności. Rozpoznawanie i identyfikowanie przypadkowej złożoności mechanizmów może przebiegać na dwa sposoby. Pierwszym z nich jest identyfikacja typów przypadków - czyli konstruowanie empirycznych typologii. Drugim z nich jest szacowanie związków przyczynowo-skutkowych, które powodują wystąpienie danego efektu oddziaływania. Gdy dany efekt jest wynikiem kilku kombinacji warunków, wówczas trudno jest dokonać estymacji wpływu tego najistotniejszego warunku. Obie te metody są do siebie podobne - pierwsza polega na upraszczaniu właściwości przypadków, a potem na konstruowaniu modelu opartego na nich, druga natomiast upraszcza złożoność wśród kombinacji, które prowadzą do danego rezultatu ${ }^{31}$. Strategie te są obecne w metodologii ilościowej i jakościowej. Jakościowa analiza porównawcza jednak stara się wybrać najbardziej efektywne możliwości z obydwu metodologii i połączyć je w sposób, który pozwoli objąć jak największą różnorodność przypadków.

27 E. Shorter, C. Tilly, Strikes in France, 1830-1968, Cambridge 1974.

28 J. Paige, Agrarian Revolution: Social Movements and Export Agriculture in the Underdeveloped World, New York 1975.

29 J. Stephens, The Transition from Capitalism to Socialism, London 1979.

30 C.C. Ragin, The Comparative Method: Moving Beyond..., s. 23.

31 Tamże, s. 31. 
Metodologie jakościowe nastawione są na analizę konkretnego przypadku przy pomocy typów idealnych ${ }^{32}$, do których są porównywane. Podstawy tej metodologii zostały sformułowane przez Johna Stuarta Milla ${ }^{33}$. Pierwszą z nich jest metoda porozumienia, która polega na odnalezieniu powtarzających się warunków prowadzących do danego rezultatu oraz zdeterminowaniu, który z warunków występuje niezmiennie i niezależnie. Drugą z metod jest pośrednia analiza różnic, która polega na zidentyfikowaniu wpływu korzystnych czynników na konieczny warunek oraz wpływu negatywnych czynników na dopuszczalny warunek. Strategie Milla jednak nie uwzględniały wieloaspektowego wpływu na rezultat. Oznacza to, że metody nastawione na analizę konkretnego przypadku są przydatne jedynie do rozpoznawania zależności lub wskazywania schematów, ale nie do wyjaśniania odmian i różnic w nich istniejących. Aby więc zidentyfikować wspólne przyczyny potrzebne jest także wyjaśnienie wspólnego rezultatu danych przypadków. Uogólniona strategia badania przy pomocy analizy przypadku składa się z trzech stadiów ${ }^{34}$. Pierwszym z nich jest znalezienie zasadniczych podobieństw wśród przedmiotu badań, które prowadzą do tego samego skutku. Potem należy ustalić, czy owe podobieństwa są przypadkowo związane ze zjawiskiem, czy kierują nimi jakieś własności. Następnie, gdy podstawy podobieństw są zdefiniowane, można przejść do formułowania wyjaśnienia. Metodologia analizy przypadku ma jednak pewne ograniczenia ${ }^{35}$. Gdy przypadki są traktowane jako całości, identyfikacja poszczególnych czynników, które wpływają na rezultat, staje się niemożliwa. Dodatkowo, aby dogłębnie zbadać każdy z przypadków, ich liczba musi być względnie mała (od dwóch do sześciu przypadków). Należy zaznaczyć, że gdy liczba istotnych warunków wzrasta, rośnie także liczba logicznie możliwych konfiguracji.

Podejście ilościowe jest zorientowane na empiryczne testowanie teorii. Jest to możliwe dzięki dużym próbom, które pozwalają zachować większą wiarygodność i prawomocność danych oraz gwarantują wskazanie relacji między zmiennymi ${ }^{36}$. Metodologia ilościowa służy głównie do objaśniania zjawisk makrospołecznych, skupiając się głównie na uogólnia-

32 M. Weber, The Methodology of Social Sciences, New York 1949.

33 J.S. Mill, System logiki dedukcyjnej i indukcyjnej, tłum. Cz. Znamierowski, wstęp K. Szaniawski, PW, Warszawa 1962.

34 D. Byrne, C. Ragin, Handbook of Case-Based Methods, London 2009.

35 A. George, A. Bennett, Case Studies and Theory Development in the Social Sciences, Cambridge 2005, s. 57 .

36 Zob. J. Buttolph Johnson, H.T. Reynolds, J.D. Mycoff, Metody badawcze w naukach politycznych, Warszawa 2010, s. 228-261. 
niu wyników, pomijając opis złożoności zjawisk. Przeprowadzenie analizy ilościowej składa się z kilku etapów. Pierwszym z nich jest określanie hipotezy, która ma być sprawdzana. Następnie należy zbadać związki łączące główne cechy danego zjawiska, zwracając uwagę to, że aby hipoteza mogła zostać poddana analizie musi być ona osadzona konkretnie na danych empirycznych. Oznacza to, że wyjaśnienia współtworzące dane zjawisko muszą być przedstawione w postaci zmiennych. Dodatkowo, należy skonstruować odpowiedniej wagi wskaźniki empiryczne. Następnie można przeprowadzić statystyczne analizy, które są stosowane do testowania danej teorii w kontekście alternatywnych wyjaśnień. Metodologia ta pozwala badaczom na formułowanie ogólnych twierdzeń dotyczących zjawisk społecznych, jak również na porównywanie ich ze sobą, z uwagi na duża liczbę analizowanych przypadków jednocześnie.

Jakościowa analiza porównawcza implementuje pewne rozwiązania analityczne z metodologii ilościowej ${ }^{37}$. Metody statystyczne pokazują, że im większa próba, tym wyższe prawdopodobieństwo uzyskania wyników istotnych statystycznie, a hipotezy zerowe są odrzucane. Metody statystyczne umożliwiają także łatwe uwzględnianie alternatywnych wyjaśnień podczas testowania teorii. Pokazują one, że aby sformułować generalizacje potrzebne są silne dowody (korelacje). Podejście ilościowe ma jednak wiele wad, które są niwelowane w ramach QCA. Pierwszą z nich jest abstrakcyjność i zbyt duże uogólnienie, które utrudnia zrozumienie kompleksowych i złożonych zjawisk. Po drugie szacowanie opiera się na względnej powtarzalności różnych typów przypadków ${ }^{38}$. Zbiory danych z założenia powinny być reprezentatywne dla danej populacji, jednak nie zawsze jest to możliwe do określenia. W związku z tym wynik końcowy analizy może odzwierciedlać wyłącznie zależności empiryczne, występujące tylko w zbiorze przypadków poddanych analizie. Model ukrytego związku przyczynowego nie uwzględnia oddzielenia od siebie poszczególnych warunków, są one dodawane jednocześnie, tworząc dany rezultat. Utrudnione jest więc określanie, czy któryśs z nich jest elementem zależności bezpośredniej, czy też stanowi element zależności pośredniej.

Proces badawczy, w którym jest stosowana metoda QCA, ma charakter iteracyjny, czyli obejmuje porównania odnoszące się do wybranych przypadków, stanowiących klasę obiektów rzeczywistości politycznej. W modelowym ujęciu ten proces badawczy składa się z sześciu eta-

37 C.C. Ragin, The Comparative Method: Moving Beyond..., s. 65.

38 Tamże, s. 26. 
pów: (1) zdefiniowania pytania badawczego, (2) wyboru przypadków do analizy (jednostki obserwacji/jednostki analizy), (3) analizy czynników składających się na konfigurację cech tworzących każdy przypadek, (4) stworzenia zbioru cech pod kątem ich występowania/braku (lub zakresu występowania) w odniesieniu do wszystkich przypadków poddanych analizie, (5) sformalizowanej analizy porównawczej wszystkich przypadków (w oparciu o algebrę Boole’a), (6) przygotowania wniosków końcowych ${ }^{39}$. W polskiej literaturze przedmiotu proces badawczy, który opiera się na wykorzystaniu QCA, jest opisywany następująco: „Analiza polega na określeniu i obliczeniu wszystkich kombinacji zmiennych występujących w zbiorze danych, a następnie zastosowaniu zasad logicznego wnioskowania, w celu określenia, które z opisowych wnioskowań lub implikacji dotyczą analizowanych danych." 40 Badacz dokonuje selekcji czynników, przypisuje im określone wartości w zależności od zakresu ich występowania, tworzy konfiguracje czynników (oparte na założeniach logicznych), dokonuje weryfikacji empirycznej ich występowania, identyfikuje zależności przyczynowe, dokonuje interpretacji uzyskanych wyników w kontekście dotychczasowej wiedzy teoretyczno-empirycznej.

Selekcję czynników do analizy poprzedza proces kalibracji, czyli „określanie wartości za pomocą których zostanie przetransformowane konkretne nasilenie zjawiska empirycznego" ${ }^{41}$. W naukach społecznych przeprowadzenie procesu kalibracji jest utrudnione ze względu na brak uniwersalnie występujących wartości bazowych, umożliwiających stworzenie standardu pomiaru, co nie jest problemem w naukach przyrodniczych. Kalibracja w odniesieniu do QCA powinna zatem każdorazowo uwzględniać charakterystykę empiryczną analizowanego zjawiska, na którą wpływa kontekst czasowo-przestrzenny. Natomiast wybór przypadków do analizy opiera się na ich istotności empirycznej (nie należy jej utożsamiać z istotnością statystyczną), która wskazuje, czy uwzględnienie danego przypadku w procesie badawczym podniesie wartość poznawczą całej analizy. Jeśli badacz uzna, że tak będzie, wówczas powinien taki przypadek włączyć do analizy. Na tym etapie procesu badawczego przypadki można podzielić

39 Zob. N. Legewie, An Introduction to Applied Data Analysis with Qualitative Comparative Analysis (QCA) [88 paragraphs], «Forum Qualitative Sozialforschung / Forum: Qualitative Social Research» 2013, vol. 14, http://nbn-resolving.de/urn:nbn:de:0114-fqs1303154 (28.01.2020).

40 A. Krakowiak-Bal, U. Ziemiańczyk, Rozmyta jakościowa analiza porównawcza (fsqca) w ocenie transferu wiedzy, «Infrastruktura i Ekologia Terenów Wiejskich» 2016, vol. III, s. 1029.

41 M. Polakowski, D. Szelewa, Zasitki dla osób bezrobotnych w Europie Środkowo-Wschodniej - analiza konfiguracyjna, «Problemy Polityki Społecznej» 2008, vol. 11, s. 112. 
na trzy kategorie: pozytywne (dana cecha występuje w pełni), negatywne (dana cecha nie występuje), tzw. szara strefa (dana cecha występuje w określonym natężeniu) ${ }^{42}$. Proces identyfikacji poziomu występowania danej cechy w konfiguracji cech, które charakteryzują dany przypadek, jest kluczowym etapem, bo od niego zależy wybór sposobu analizy danych w ramach etapu analizy formalnej (opartej na algebrze Boole’a). Zmienne, które są empiryczną reprezentacją cech danej jednostki analizy mogą być podzielone na kilka typów: (1) zmienne dychotomiczne (ang. crisp set) - dana cecha występuje w pełni lub nie występuje - 1 lub 0; (2) zmienne trójwartościowe (ang. three-value set) - 1, 0.5, 0; (3) zmienne czterowartościowe - 1, 0.67, 0.33, 0; (4) zmienne sześciowartościowe $-1,0.8,0.6$, 0.4, 0.2, 0; (5) zmienne „ciagłe” $-1,0.5<\mathrm{X}_{\mathrm{i}}<1,0.5,0<\mathrm{X}_{\mathrm{i}}<0.5,043$. Opisanych typy zmiennych nie należy interpretować $\mathrm{w}$ kontekście skal pomiarowych, które występują w przypadku badań ilościowych i mogą być obiektem przekształceń w ramach statystycznej analizy danych (operacje arytmetyczne). Są one odzwierciedleniem stopnia przypisania danej jednostki analizy do określonej kategorii danej cechy, ze względu na zbliżanie się natężenia takiej cechy do kategorii „występuje w pełni”. Koncepcja „fuzzy set” została wprowadzona w latach 60. ub. wieku przez L. Zadeh'a, który definiuje taki zbiór cech następująco: „jest to klasa obiektów opisana przy pomocy zakres występowania. Taki zestaw cech jest charakteryzowany przy pomocy funkcji występowania (charakterystyki), która przypisuje każdemu obiektowi zakres występowania w przedziale od zero do jedności” ${ }^{44}$. Narzędziem analitycznym, które służy do tego, aby określić czy daną cechę można przedstawić za pomocą zmiennych dychotomicznych lub zmiennych mających więcej niż dwie kategorie, jest wykres rozrzutu pomiędzy dwiema zmiennymi. Jeśli punkty na tym wykresie znajdują się powyżej lub poniżej linii przekątnej na wykresie rozrzutu, wówczas można zakładać występowanie określonego rodzaju relacji zaliczanych do typu „fuzzy set”.

C.C. Ragin wskazuje na trzy podstawowe zalety stosowania relacji „fuzzy set” w ramach QCA: możliwość przedstawienia bardziej zróżnicowanej reprezentacji empirycznej danej koncepcji teoretycznej, przy zasto-

42 J. Mahoney, G. Goertz, The Possibility Principle: Choosing Negative Cases in Comparative Research, «The American Political Science Review» 2004, vol. 98, s. 654-655.

43 C.C. Ragin, Redesigning Social Inquiry: Fuzzy Sets and Beyond, Chicago-London 2008, s. 31.

44 L. Zadeh, Fuzzy Sets, «Information and Control»1965, vol. 8, s. 338, https://wwwliphy.ujf-grenoble.fr/pagesperso/bahram/biblio/Zadeh_FuzzySetTheory_1965.pdf (30.01.2020). 
sowaniu zakresu występowania, niż przy pomocy prostego występowania danej cechy lub jej braku, jednoczesne werbalne przedstawienie zróżnicowania i dwuznaczności w sposób uporządkowany dzięki procesowi kalibracji danych i przypisania cechy do danego zbioru, możliwość opisania relacji wspólnej części dwóch zbiorów lub zawierania się (warunek konieczny i wystarczający związku przyczynowo-skutkowego) ${ }^{45}$. W ten sposób badacz może analizować różne konfiguracje cech i przypisanych im zmiennym w odniesieniu do stopnia, w jakim spełniają one kryterium warunku koniecznego i/lub warunku wystarczającego w związku przyczynowo-skutkowym.

Takie rozumienie przyczynowości umożliwia wariantowe interpretowanie warunków początkowych, prowadzących do określonego stanu końcowego badanego przypadku (czyli konfiguracji cech). W QCA przyczynowość można pojawiać się w czterech formach: 1) warunek konieczny - czynnik zawsze występuje jako przyczyna stanu końcowego (np. wojna z wrogiem zewnętrznym jako warunek konieczny rewolucji), 2) warunek wystarczający - czynnik powoduje stan końcowy, ale jednocześnie mogą pojawiać się inne czynniki przyczynowe (np. represje ze strony państwa mogą spowodować wystąpienie protestów społecznych), 3) warunek konieczny i jednocześnie niewystarczający - czynnik jest elementem składowym warunku wystarczającego (np. problemy z produkcją żywności jako element składowy wojny domowej - czyli warunku wystarczającego prowadzącego do wystąpienia rewolucji), 4) warunek wystarczający i jednocześnie niekonieczny - czynnik jest elementem składowym warunku koniecznego (np. problemy z produkcją żywności jako element składowy wojny domowej, które niekoniecznie muszą prowadzić do wystąpienia rewolucji ${ }^{46}$. Warto podkreślić, że to, czy dana cecha będzie w konfiguracji pełniła funkcję warunku koniecznego lub/i wystarczającego, jest zależne od kontekstu społeczno-ekonomicznego, bo zmiany w systemie ekonomicznym i społecznym mogą dane cechy rzeczywistości społecznej aktywizować jako warunki wystąpienia związku przyczynowo-skutkowego (np. partie lewicowe w systemie politycznym jako warunek konieczny powstania welfare state (państwa dobrobytu).

Aby było możliwe zidentyfikowanie związku przyczynowo-skutkowego w danym zbiorze przypadków, badacz musi uprzednio przygotować

45 C.C. Ragin, P. Pennings, Fuzzy Sets and Social Research, «Sociological Methods \& Research» 2005, Vol. 33, s. 425.

46 S.R. Lucas, A. Szatrowski, Qualitative Comparative Analysis in Critical Perspective, «Sociological Methodology» 2014, vol. 44, s. 7. 
zbiór cech pod kątem ich występowania/braku (lub zakresu występowania) w odniesieniu do wszystkich przypadków obecnych w tym zbiorze. Ten etap jest realizowany przy wykorzystaniu tabeli prawdy (ang. truth table), którą C.C. Ragin definiuje następująco: „Przypadki posiadające takie same profile warunków przyczynowych, które są pogrupowane razem w celu sprawdzenia czy dana kombinacja tych warunków wpływa na wystąpienie danego stanu empirycznego. Każda kombinacja warunków przyczynowych jest poddana analizie oddzielnie, jako określony zestaw wariantów cechy"47. Tabela prawdy obejmuje określoną liczbę komórek tabeli, w której pierwszy wiersz tabeli zawiera hipotetyczne warunki przyczynowe (ich liczba zależy od założeń teoretycznych i stanu wiedzy empirycznej), a kolejne wiersze wskazują na zakres występowania danej cechy (w ramach kontinuum od 0 do jedności: binarny wariant lub wariant wielowartościowy). Zatem tabela prawdy jednocześnie ujmuje dwa aspekty analizy: (1) logiczny - zawiera wszystkie konfiguracje cech składających się na warunki przyczynowe i (2) empiryczny - przypisane do każdego wiersza konfiguracje występowania cechy dla danego przypadku. Np. liczba komórek zawierających warianty cech w tabeli zależy od liczby przypadków oraz potencjalnych warunków przyczynowych (czyli cech przypadku) dla tabeli składającej się z trzech warunków początkowych i dziesięciu przypadków będzie wynosiła 30 komórek, które zostaną poddane analizie. Podczas konstrukcji tabeli, moga pojawić się w niej wiersze, w których komórki tabeli są puste, co oznacza, że dana kombinacja warunków oparta na kryterium logicznym nie ma empirycznej reprezentacji (brak przypadku, ang. reminder). Od badacza zależy, w jaki sposób będzie interpretował wystąpienia takiej kombinacji cech bez odpowiadającego mu przypadku - może go usunąć lub uwzględnić na kolejnym etapie analizy (sformalizowana analiza porównawcza wszystkich przypadków) ${ }^{48}$. Tabela prawdy ma służyć redukcji zbioru danych, czyli usunięcia wariantów cech, które okażą się nieistotne empirycznie dla stworzenia teoretycznego opisu analizowanego zjawiska.

Przekształcenia matrycy danych, które zawarte są w tabeli prawdy (w formie określonych konfiguracji wariantów cech, stanowiących kombinacje potencjalnych warunków pojawienia się związków przyczynowo-skutkowych w zbiorze danych jakościowych), opierają się na

47 C.C. Ragin, The Comparative Method: Moving Beyond..., s. xxvii.

48 C.C. Ragin, J. Sonnett, Between Complexity and Parsimony: Limited Diversity, Counterfactual Cases, and Comparative Analysis, «Department of Sociology, UCLA. Theory and Research in Comparative Social Analysis» 2004, Paper 17, s. 3-4. 
rachunku zbiorów, który jest częścią teorii mnogości (ang. set theory) i jest określany jako algebra Boole'a. Dwa dane zbiory pozostają w określonych relacjach: (1) suma zbiorów, (2) różnica zbiorów, (3) iloczyn (cześć wspólna zbiorów) ${ }^{49}$. Na podstawie tych trzech relacji jest przeprowadzana operacja logicznych przekształceń wariantów cech. Mogą one przyjmować następującą postać: (1) przecięcie dwóch zbiorów A i $B-$ czyli $A * B$ (np. jeśli $A=0.33$, i $B=1$, to $A * B=0.33$ ); (2) połączenia dwóch zbiorów $\mathrm{A}$ i $\mathrm{B}-$ czyli $\mathrm{A}+\mathrm{B}$ (np. $\mathrm{A}=0.33$, $\mathrm{i} B=1$, to $\mathrm{A}+\mathrm{B}=1$ ), (3) relacja negacji $\sim \mathrm{A}$, inaczej $\mathrm{a}, \sim \mathrm{A}=1-\mathrm{A}$ (np. $\mathrm{A}=0.33$, to $\sim \mathrm{A}=1-0.33=0.67)^{50}$. Wykorzystanie tych trzech typów operacji logicznych umożliwia uproszczenie istniejących wariantów cech do postaci, która będzie odzwierciedlała możliwie najszerszy zbiór zidentyfikowanych na poziomie danych jakościowych cech przypadków - to uproszczenie jest określane jako „zasada minimalizacji”. Porównujemy warunki przyczynowe w poszczególnych wierszach tabeli i odszukujmy taki warunek różnicujący obie kombinacje cech, a następnie go usuwamy. Należy wskazać, iż litera „A” oznacza występowanie danej cech, natomiast litera „a” jej brak. Przykładowo: (1) Abc porównujemy z ABc i otrzymujemy kombinację Ac, (2) Abc porównujemy z AbC i otrzymujemy Ab, (3) aBc porównujemy z ABc i otrzymujemy Bc ${ }^{51}$. W wyniku tej procedury porównywania otrzymujemy listę warunków, które determinują wystąpienie/lub brak istnienia relacji przyczynowo-skutkowej dotyczącej interesującego nas zjawiska politycznego. W efekcie badacz uzyskuje równania będące formalnym zapisem warunków, których kombinacje empiryczne prowadzą do wystąpienia zjawiska, będącego obiektem analizy w ramach metody QCA.

Rozwinięciem tego sposobu interpretacji teoretycznej kombinacji empirycznych wariantów cech jest wprowadzenie przez C.C. Ragina dwóch wskaźników w odniesieniu do analizy cech, którym badacz przypisuje więcej niż dwie wartości na podstawie ich empirycznej charakterystyki, co stanowi element koncepcji „fuzzy set”. Te wskaźniki to: (1) spójność (ang. consistency), (2) pokrycie (ang. coverage). Ich interpre-

49 Zob. W. Marciszewski, VIII. Rachunek zbiorów, [w:] W. Marciszewski (red.), Logika formalna: zarys encyklopedyczny z zastosowaniem do informatyki i lingwistyki, Warszawa 1987, s. 93.

50 N. Legewie, An Introduction to Applied Data Analysis with Qualitative Comparative Analysis (QCA) [88 paragraphs], «Forum Qualitative Sozialforschung / Forum: Qualitative Social Research»2013, vol. 14, http://nbn-resolving.de/urn:nbn:de:0114-fqs1303154 (28.01.2020).

51 C.C. Ragin, The Comparative Method: Moving Beyond..., s. 94. 
tacja jest analogiczna do tej, która pojawia się w odniesieniu do wyników statystycznej analizy danych ilościowych: istotność statystyczna i siła związku między zmiennymi ${ }^{52}$. Wskaźnik spójności pozwala na zbadanie, w jakim zakresie poszczególne kombinacje cech określają warunki konieczne wystąpienia związku przyczynowo-skutkowego. Jest to wskaźnik analogiczny do istotności statystycznej - pozwala na podjęcie przez badacza decyzji dotyczącej potwierdzenia lub odrzucenia jego hipotezy badawczej w zakresie teorii lub relacji między daną kombinacją cech i badanym zjawiskiem. Natomiast wskaźnik pokrycia informuje o sile zależności między cechami konfiguracji i badanymi zjawiskiem. Tak więc w ramach tabeli prawdy możliwe są takie wyniki analiz, w których badacz ma do czynienia z wysoką wartością wskaźnika spójności i niską wartością wskaźnika pokrycia. Za wartościowe poznawczo w analizie danych przy zastosowaniu metody QCA (jej wariant fuzzy set QCA, czyli fsQCA) uznaje się takie wyniki analizy, w których wartość wskaźnika spójności jest najbliższa 1.0. Badacz powinien więc najpierw sprawdzić, jaki jest poziom wskaźnika spójności, a dopiero potem - jeśli jego wartość jest uznana przez niego za wystarczająco wysoką - przystąpić do obliczenia wartości wskaźnika pokrycia ${ }^{53}$. Jeśli badacz posiada dostęp do wyników innych badań opartych na metodzie QCA, które dotyczą obiektu jego zainteresowań badawczych, wówczas może dokonać porównań pozwalających na stworzenie twierdzeń o poziomie ogólności zbliżonym do tego, który posiadają generalizacje empiryczne, będące efektem badań ilościowych ${ }^{54}$. W ten sposób badacz realizuje szósty, ostatni etap procesu badawczego - przygotowuje wnioski końcowe, które potwierdzają istniejący zakres wiedzy teoretycznej, np. o sferze stosunków politycznych i aktorach politycznych lub go falsyfikują. Wzmocnieniem tej metody może być zastosowanie procedury triangulacji danych, w której obok danych jakościowych są analizowane także dane ilościowe dotyczące obiektu, będącego celem zainteresowań badacza ${ }^{55}$.

Podsumowując przedstawione powyżej etapy procesu badawczego z wykorzystaniem metody QCA, można stwierdzić, że powinna być ona

52 Tenże, Redesigning Social Inquiry..., s. 44-46.

53 Tamże, s. 55.

54 Zob. G. Rohwer, Qualitative Comparative Analysis: A Discussion of Interpretations, «European Sociological Review» 2011, vol. 27, s. 728-740.

55 Przykład takiej strategii badawczej (połączenie fuzzy set QCA i analizy regresji): A. Katz, M. vom Hau, J. Mahoney, Explaining the Great Reversal in Spanish America: Fuzzy-Set Analysis Versus Regression Analysis, «Sociological Methods \& Research» 2005, vol. 33, s. 539-573. 
postrzegana przez badaczy jako dodatkowy element strategii badawczej, a nie jako jej główny komponent. Wynika to z jej eksploracyjno-deskryptywnego charakteru, bowiem identyfikacja związków przyczynowo-skutkowych w ramach QCA nie przesądza o tym, jakiego rodzaju zależności funkcyjno-strukturalne je tworzą. Odpowiedzi na to pytanie można udzielić dzięki analizie danych ilościowych. Natomiast QCA rozumiana jako technika badawcza służąca wyłącznie do detekcji określonego rodzaju relacji empirycznych w zbiorze danych, umożliwia badaczowi: dokonanie uporządkowanej prezentacji danych empirycznych, sprawdzenie spójności danych w celu wykrycia sprzeczności konfiguracji cech (analizowane przypadki mają same warunki przyczynowe, ale różne skutki w związku w związku przyczynowo-skutkowym) testowanie hipotez i teorii, przeprowadzenie testu tezy badawczej bez określania jej kierunkowego charakteru, stworzenie nowego zestawu hipotez, dotychczas nieobecnych w debacie teoretycznej ${ }^{56}$. Właściwie ukierunkowane wykorzystanie przez badacza potencjału poznawczego metody QCA (rozumianej także jako technika) wymaga od niego znajomości sposobów analizy danych, które są dostępne w oprogramowaniu do analiz QCA. Do grupy najczęściej wykorzystywanych w tym celu programów komputerowych należy fs/QCA.

Program fs/QCA został stworzony do wykonywania analiz metodą porównawczą za pomocą komputera ${ }^{57}$. Oprogramowanie pozwala na wykonanie jakościowej analizy porównawczej przy wykorzystaniu gotowych zbiorów danych. Program opiera się na trzech typach zakładek. Pierwsza z nich jest ekranem głównym, na którym wyświetlają się wszystkie załadowane zbiory danych, wyniki analiz, a także raporty końcowe. Drugą zakładką jest arkusz obliczeniowy, który wyświetla się po załadowaniu pliku ze zbiorem danych. Służy ona do kontroli danych, ich edycji i do przeprowadzania analiz. Trzecim typem zakładki są dodatkowe okna, które wyświetlają się podczas kolejnych stadiów analizy. Każda z nich wykonuje konkretne polecenia - przykładowo dotyczące tabeli prawdy.

Do analizy w fs/QCA można używać różnych typów plików w formacie arkusza kalkulacyjnego - SPSS, Excel, OpenCalc, GoogleSheets. Aby załadować plik danych należy otworzyć program, a następnie wybrać z menu głównego [File/Open/Data] i kliknąć na odpowiedni plik. Wów-

56 D. Berg-Schlosser et al., Qualitative Comparative Analysis (QCA) as an Approach, s. 15-16, https://us.sagepub.com/sites/default/files/upm-assets/23236_book_item_23236.pdf (11.01.2020).

57 Program jest bezpłatny i można go pobrać zarówno na komputer z systemem operacyjnym Windows jak i Mac OS za pośrednictwem strony internetowej: http://www.socsci. uci.edu/ cragin/fsQCA/software.shtml (28.07.2020). 
czas pojawi się okno ze zbiorem danych, w którym będą przeprowadzane analizy, wyniki analiz natomiast będą wyświetlane w oknie głównym. Przed rozpoczęciem analizy należy pamiętać o kilku ważnych szczegółach: pierwszy rząd arkusza kalkulacyjnego musi składać się z nazw zmiennych; każda z kolumn musi być jednolita w treści - to znaczy numeryczna albo alfabetyczna; nie może być braków danych.

Aby przeanalizować dane, używając funkcji statystyk opisowych, należy wybrać [Analyze/Statistics/Descriptives]. Następnie pojawi się okno, które pozwoli określić warunki analizy. Po ich wybraniu należy kliknąć [OK], po czym wynik analizy pokaże się w głównym oknie. Opcja ta pozwala określać takie wskaźniki jak: częstotliwość, wartości minimalne i maksymalne, brakujące dane oraz odchylenie standardowe. Można także tworzyć tabele przestawne porównując ze sobą warunki - wówczas należy kliknąć [Analyze/Statistics/Crosstabs]. W celu stworzenia wykresów rozrzutu (XY plots) ${ }^{58}$, należy kliknąć [Graphs/Fuzzy/ XY Plot], wówczas na ekranie głównym pojawi się okno, w którym należy określić poszczególne warunki, zestawiając je z innymi warunkami lub wynikami. Liczby wyświetlające się w prawym dolnym rogu, w zależności od zaznaczonych właściwości będą określały spójność, pokrycie lub niezbędny warunek.

Aby skonstruować tabelę prawdy należy kliknąć [Analyze/FuzzySets/ TruthTableAlgorithm]. Wówczas pojawia się zakładka, w której możliwe jest określenie warunków oraz wyników dalszej analizy. Aby wybrać oczekiwany rezultat należy wybrać z menu [Set] albo [Set Negated]. Dodatkowo, jeśli określane są warunki, należy wybrać odpowiednie z listy i kliknąć [Add]. Wskazane jest, aby na samym początku procesu badawczego określić wszystkie warunki (nie przekraczając maksymalnej ilości 10). W następnych etapach badania należy tę liczbę redukować, wraz z doprecyzowaniem modelu usuwając te warunki, które są nieistotne. Po określeniu modelu należy kliknąć [Run], wówczas wyświetli się okno przedstawiające tabelę prawdy. Tabela przedstawia wszystkie możliwe kombinacje zbioru danych ze zdefiniowanymi warunkami oraz ich specyfikacja. Kolumna [number] pokazuje, ile pomiarów empirycznych ma dana konfiguracja. Wówczas można dowiedzieć się, czy występuje ona często, rzadko lub czy w ogóle się nie pojawia. Informacje te dają pierwszy wgląd w modele i wzory pojawiające się w zbiorze danych. Kolumna

58 C.C. Ragin, USER'S GUIDE TO: Fuzzy-Set./Qualitative Comparative Analysis, July 2017, s. 27-29, http://www.socsci.uci.edu/ cragin/fsQCA/download/fsQCAManual. pdf (21.01.2020). 
[rawconsistency] wskazuje jak konsekwentnie wynik oddaje konfigurację podzbioru. Dzięki temu można określić, czy należy brać pod uwagę dany wynik i czy jest on wiarygodny.

Zanim przeprowadzimy analizę danych, najpierw należy ustalić częstotliwość graniczna, która będzie uznawana jako wyznacznik, ile musi występować przypadków w danym podzbiorze, aby włączać go do analizy. Trzeba także określić spójność graniczną, która determinuje próg, przy którym dana kombinacja warunków jest uważana za przyczyniającą się do wyniku. Aby tego dokonać, należy kliknąć [Edit/Delete and Code ...] w prawnym górnym rogu tabeli prawdy, zdefiniować limity, a następnie zaakceptować klikając [OK]. Następnie, jeśli nie wystąpiły żadne błędy, należy zapisać tabelę prawdy klikając [File/Save as CSV File]. Wówczas można przejść do ostatniego etapu analizy - minimalizacji tabeli prawdy. Proces minimalizacji prowadzi do zdefiniowania specyfikacji, czyli primeimplicants ${ }^{59}$, które są przyczynami danych procesów. Przykładowo jeśli $\mathrm{ABC}$ i $\mathrm{AB} \sim \mathrm{C}$ zostały zredukowane do $\mathrm{AB}$ nie mogą być zredukowane (czyli zminimalizowane) już bardziej według algebry Boole’a są one wtedy uznane za zasadnicze wskaźniki (primeimplicants). Minimalizacja jest uznawana za zakończona, gdy owe zasadnicze wskaźniki pokrywają wszystkie zasadnicze wyrażenia (primeexpressions) ${ }^{60}$, czyli określone wcześniej kombinacje. Aby wybrać jeden lub więcej zasadniczych wskaźników, należy dokonać selekcji z menu głównego [PrimeImplicant Chart], wówczas pojawi się okno [PI Chart] służące do określania możliwych zasadniczych wskaźników. Pierwsza kolumna określa możliwe wybory, każdy z wierszy określa jeden wskaźnik. Wszystkie kolejne kolumny reprezentują kolejne wiersze tabeli prawdy. Klikając na odpowiednią komórkę w pierwszym rzędzie pojawi się pole [Prime], które wyświetli odpowiedni zasadniczy wskaźnik. Aby wybrać konkretny zasadniczy wskaźnik należy kliknąć na odpowiednią komórkę w pierwszej kolumnie z lewej, która wówczas zmieni kolor z szarego na biały. Wtedy liczba w lewym górnym rogu zmniejszy się o jeden. Kiedy przynajmniej jeden zasadniczy wskaźnik zostanie wybrany do każdego wiersza tabeli prawdy, liczba w lewym górnym rogu pokaże zero i zmieni kolor na zielony, wtedy należy kliknąć [OK]. Przy zmianie wyboru wskaźnika właściwego należy wybrać [ClearAll] i zacząć od początku. Ostatnim krokiem do otrzymania

59 C.C. Ragin, USER'S GUIDE TO..., s. 33-35.

60 N. Legewie, An Introduction to Applied Data Analysis with Qualitative Comparative Analysis (QCA) [88 paragraphs], «Forum Qualitative Sozialforschung / Forum: Qualitative Social Research» 2013, vol. 14, http://nbn-resolving.de/urn:nbn:de:0114-fqs1303154 (28.01.2020). 
wyników jest określenie uproszczonych założeń. Aby je określić należy wejść w opcje [Intermediate Solution] i zdecydować w jakich okolicznościach dany warunek może prowadzić do oczekiwanego wyniku. Każdemu warunkowi zostaje przyporządkowana odpowiednia specyfikacja. Jeśli badacz jest pewny, że dany warunek prowadzi do oczekiwanego wyniku należy zaznaczyć [Present], jeśli brak danego warunku prowadzi do oczekiwanego wyniku należy zaznaczyć [Absent]. Jeśli badacz ma wątpliwość należy zaznaczyć [PresentorAbsent]. Aby przetestować model należy kliknąć [Run]. Wynik pokaże się w nowym oknie. Aby go edytować, zmienić warunki, uproszczone założenia lub zasadnicze wskaźniki należy kliknąć [Edit]. Można także zapisać wynik [File/Save as CSV File] lub go wyeksportować wybierając format [File/Save as/Output]. Uzyskane wyniki mogą być później przedmiotem metaanalizy, przeprowadzonej przez innych badaczy, zajmujących się metodologią QCA. Warto zauważyć, iż do 2012 r. program fs/QCA był najczęściej stosowanym w analizie danych opartych na zastosowaniu metody QCA $(81,9 \%)^{61}$.

Podsumowując przedstawione rozważania na temat założeń teoretycznych, dyrektyw badawczych oraz etapów procesu analizy przypadków w ramach stosowania metody QCA, należy wskazać, iż posiada ona ograniczenia, o których badacz powinien pamiętać. W literaturze przedmiotu wskazuje się, iż: (1) zastosowanie QCA powinno być poprzedzone uzyskaniem odpowiedniego poziomu wiedzy na temat analizowanych przypadków - trzeba zwracać uwage na proces kodowania i możliwość wystąpienia błędów (analiza eksploracyjna jako główny cel badawczy stosowania QCA nie jest wskazana); (2) odpowiednie przygotowanie konfiguracji czynników przyczynowych nie opiera się na zobiektywizowanych kryteriach - istnieje możliwość pominięcia istotnych warunków przyczynowych; (3) wartość poznawcza uzyskanych wyników powinna być mierzona stopniem poszerzenia wiedzy o analizowanym przypadku (a nie tylko poziomem wyjaśnionej zmienności wyniku na podstawie warunków przyczynowych) ${ }^{62}$. Przedstawione zastrzeżenia metodologiczne mogą zostać $\mathrm{w}$ procesie badawczym zminimalizowane dzięki zastosowaniu innych metod analizy danych - jakościowych i/lub ilościowych, a także rozszerzeniu zakresu wiedzy teoretycznej o wyniki badań modyfikujących kontekst interpretacyjny w wymiarze empirycznym (np. przedstawienie

61 A. Thiem, A. Duşa, QCA: A Package for Qualitative Comparative Analysis, «The R Journal» 2013, vol. 5, s. 87.

62 C.C. Ragin et al., Complexity, Generality, and..., s. 338. 
alternatywnych wyjaśnień przyczynowych, opartych na wynikach innych badań ilościowych/jakościowych).

Obok zastrzeżeń do metody QCA, które maja charakter techniczny, pojawiają się także uwagi krytyczne o bardziej generalnym charakterze, które odnoszą się do podstaw epistemologicznych stosowania tej metody badawczej w naukach społecznych. Te uwagi odnoszą się wprost do założeń teoretycznych QCA i wskazują, iż jej jednostkami analizy nie są przypadki (pojmowane jako konfiguracje cech), ale tymi jednostkami analizy są w rzeczywistości elementy formalne samego procesu badawczego. Oznacza to, że: (1) jest to metoda nakierowana na analize zawartości komórek, które mogą być włączone lub wyłączone z analizy na podstawie arbitralnych decyzji badacza; (2) o charakterystyce cech tworzących konfigurację czynników przyczynowych danego przypadku przesądza interakcja czynników tworzących wielowymiarową przestrzeń analizy $^{63}$. Konsekwencje poznawcze takiego podejścia do cech przypadku mogą pozostawać w sprzeczności z celami badania, bo wyniki analizy stają się artefaktem metodologicznym prowadzącym do wniosków, które nie odzwierciedlają rzeczywistego charakteru relacji przyczynowych (są one niewykryte lub dochodzi do detekcji kontrfaktycznej, czyli opartej na nieobecnej empirycznie konfiguracji cech). QCA jako metoda, która ma łączyć zalety jakościowej i ilościowej analizy danych, jednocześnie stoi przed wyzwaniami, które wynikają z odmienności epistemologicznej obu rodzajów analizy danych empirycznych. Nie oznacza to jednak, że politolodzy powinni z dystansem podchodzić do stosowania QCA - wzrost liczby publikacji i coraz szerszy zakres stosowania programów komputerowych, które mają zaimplementowaną tą metodę badawcza, wskazuje, że jej popularność nie stanowi jedynie chwilowej „mody metodologicznej”, ale już na trwałe wpisała się w warsztat badawczy przedstawicieli nauk społecznych w Europie Zachodniej i Stanach Zjednoczonych Ameryki Północnej64. To sugeruje, że polscy politolodzy powinni rozważyć jej regularne wykorzystanie jako istotnego elementu własnych strategii metodologicznych i projektów badawczych.

63 S.R. Lucas, A. Szatrowski, Qualitative Comparative Analysis..., s. 65.

64 Założona w 2003 r. sieć badawcza COMPASSS (ang. skrót od słów COMPArative Methods for Systematic cross-caSe analySis) popularyzuje różne aspekty wykorzystania QCA, zob. http://compasss.org/. 


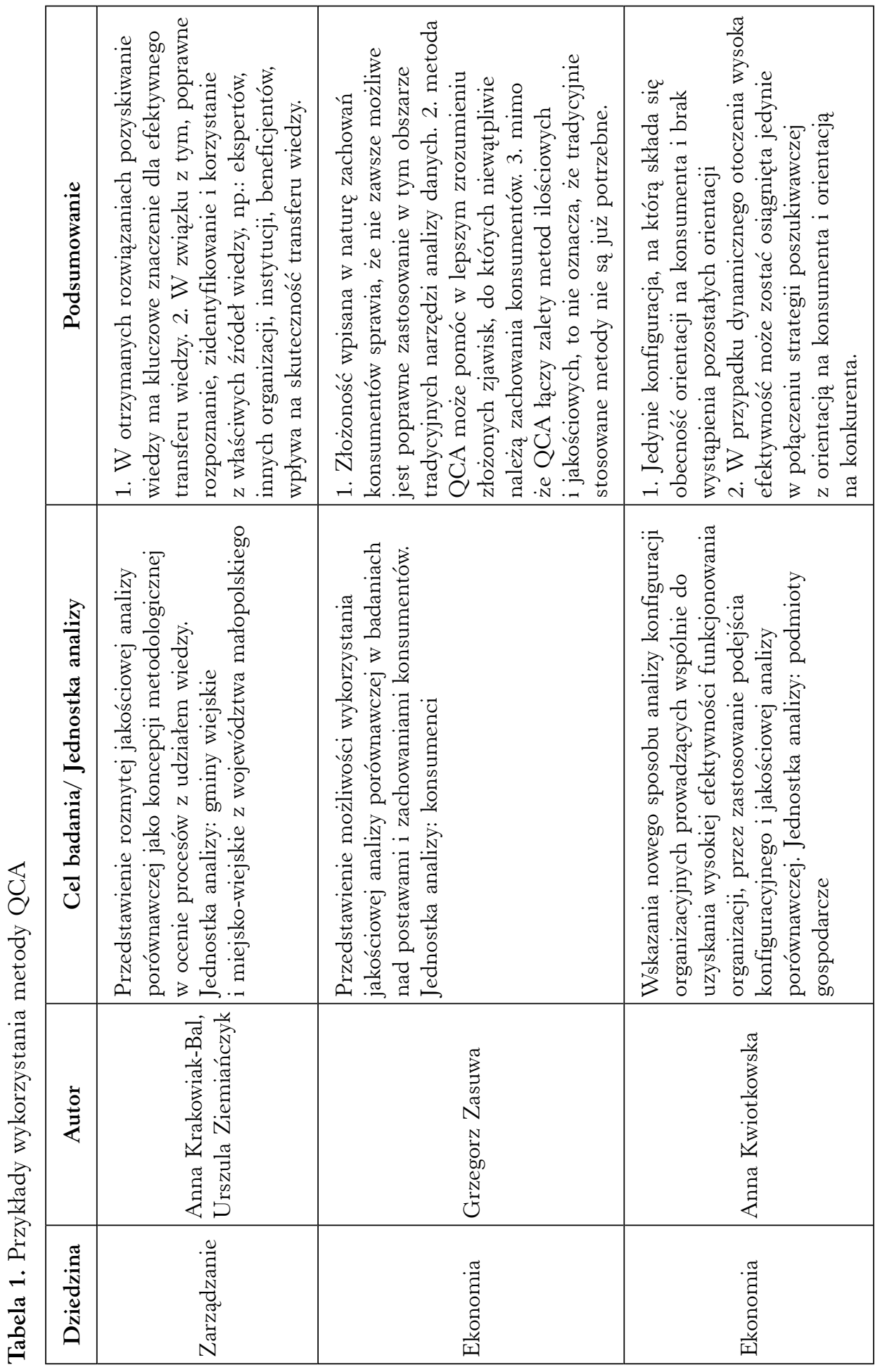



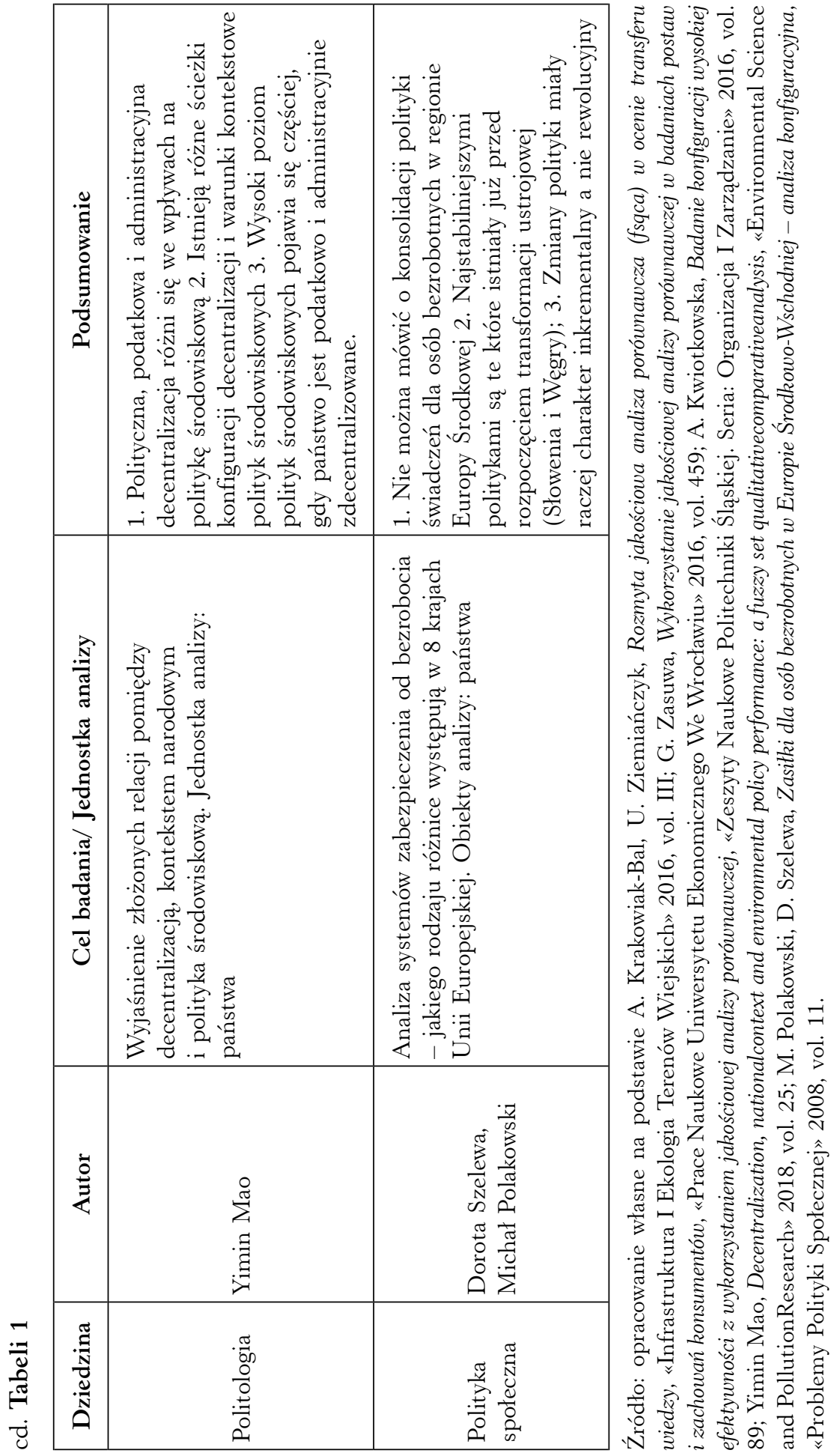


\section{Bibliografia}

Babbie E., Podstawy badan spotecznych, Warszawa 2013.

Bajer J., Badania porównawcze w politologii: zagadnienia metodologiczne, «Studia Politicae Universitatis Silesiensis» 2012, vol. 8.

Berg B.L., Qualitative Research Methods for the Social Sciences, Boston 2001.

Berg-Schlosser D., et al., Qualitative Comparative Analysis (QCA) as an Approach, https://us.sagepub.com/sites/default/files/upmassets/23236_book item_23236.pdf (11.01.2020).

Braumoeller B.F., Guarding Against False Positives in Qualitative Comparative Analysis, «Political Analysis» 2015, vol. 23.

Buttolph Johnson J., Reynolds H.T., Mycoff J.D., Metody badawcze w naukach politycznych, Warszawa 2010.

Byrne D., Ragin C., Handbook of Case-Based Methods, London 2009.

Dąbrowski A, Metoda studium przypadku krok po kroku, «Studia Socjologiczne» 2017, vol. 4.

Frankfort-Nachmias Ch., Nachmias D., Metody badawcze w naukach społecznych, Poznań 2001.

George A., Bennett A., Case Studies and Theory Development in the Social Sciences, Cambridge 2005.

Gerring J., Case Selection for Case-Study Analysis: Qualitative and Quantitative Techniques, [w:] J.M. Box-Steffensmeier, H.E. Brady and D. Collier (red.), «The Oxford Handbook of Political Methodology», doi:10.1093/oxfordhb/9780199286546.001.0001.

Gerring J., The Case Study: What it is and What it Does, [w:] C. Boix, S.C. Stokes (red.), «The Oxford Handbook of Comparative Politics», doi:10.1093/oxfor$\mathrm{dhb} / 9780199566020.001 .0001$.

Katz A., vom Hau M., Mahoney J., Explaining the Great Reversal in Spanish America: FuzzySet Analysis Versus Regression Analysis, «Sociological Methods \& Research » 2005, vol. 33.

Kincaid H., Causation in the Social Sciences, [w:] H. Beebee, C. Hitchcock, P. Menzies (red.), «The Oxford Handbook of Causation», January 2010 doi:10.1093/oxfordhb/9780199279739.001.0001. http://www.socsci.uci.edu/ cragin/fsQCA/software. shtml (28.07.2020). https://scholar.google.com (28.07.2020).

Klementewicz T., Metateoretyczne dylematy politologa $-w$ poszukiwaniu strategii badania, «Studia Politologiczne» 2009, vol. 14.

Krakowiak-Bal A., Ziemiańczyk U., Rozmyta jakościowa analiza porównawcza (fsqca) w ocenie transferu wiedzy, «Infrastruktura i Ekologia Terenów Wiejskich» 2016, vol. III.

Legewie N., An Introduction to Applied Data Analysis with Qualitative Comparative Analysis (QCA) [88 paragraphs], «Forum Qualitative Sozialforschung / Forum: Qualitative Social Research» 2013, vol. 14, http://nbn-resolving.de/urn:nbn:de:0114-fqs1303154 (28.01.2020).

Lijphart A., Comparative Politics and the Comparative Method, «The American Political Science Review» 1971, vol. 65.

Lucas S.R., Szatrowski A., Qualitative Comparative Analysis in Critical Perspective, «Sociological Methodology» 2014, vol. 44.

Mahoney J., Goertz G., The Possibility Principle: Choosing Negative Cases in Comparative Research, «The American Political Science Review» 2004, vol. 98.

Marciszewski W., VIII. Rachunek zbiorów, [w:] W. Marciszewski (red.), Logika formalna: zarys encyklopedyczny z zastosowaniem do informatyki i lingwistyki, Warszawa 1987.

Marx A., Rihoux B., Ragin C., The origins, development, and application of Qualitative Comparative Analysis: the first 25 years, «European Political Science Review» 2014, vol. 6. 
Mill J.S., System logiki dedukcyjnej i indukcyjnej, tłum. Cz. Znamierowski, wstęp K. Szaniawski, PW, Warszawa 1962.

Młyniec E., Komparatystyka, [w:] A. Antoszewski, R. Herbut (red. nauk.), Leksykon politologii wraz z Aneksem o: reformie samorzadowej, wyborach do sejmu, prezydenckich oraz gabinetach rzadowych, Wrocław 2004.

Nowak S., Metodologia badan społecznych, Warszawa 2012.

Paige J., Agrarian Revolution: Social Movements and Export Agriculture in the Underdeveloped World, New York 1975.

Polakowski M., Szelewa D., Zasitki dla osób bezrobotnych w Europie Środkowo-Wschodniej - analiza konfiguracyjna, «Problemy Polityki Społecznej» 2008, vol. 11.

Ragin C.C., Pennings P., Fuzzy Sets and Social Research, «Sociological Methods \& Research» 2005, vol. 33.

Ragin C.C., Zaret D., Theory and Method In Comparative Research: Two Strategies, «Social Forces» 1983, vol. 61.

Ragin C.C., et al., Complexity, Generality, and Qualitative Comparative Analysis, «Field Methods» 2003, vol. 15.

Ragin C.C., Sonnett J., Between Complexity and Parsimony: Limited Diversity, Counterfactual Cases, and Comparative Analysis, «Department of Sociology, UCLA.Theory and Research in Comparative Social Analysis» 2004, Paper 17.

Ragin C.C., Redesigning Social Inquiry: Fuzzy Sets and Beyond, Chicago-London 2008.

Ragin C.C., The comparative method: Moving beyond qualitative and quantitative strategies, Berkeley 1987.

Ragin C.C., The Comparative Method: Moving Beyond Qualitative and Quantitative Strategies, Oakland 2013.

Ragin C.C., The Logic of Qualitative Comparative Analysis, «International Review of Social History» 1998, vol. 43.

Ragin C.C., USER'S GUIDE TO: Fuzzy-Set./Qualitative Comparative Analysis, July 2017, s. 27-29, http://www.socsci.uci.edu/ cragin/fsQCA/download/fsQCAManual.pdf (21.01.2020).

Rohwer G., Qualitative Comparative Analysis: A Discussion of Interpretations, «European Sociological Review» 2011, No. 27.

Shorter E., Tilly C., Strikes in France, 1830-1968, Cambridge 1974.

Stephens J., The Transition from Capitalism to Socialism, London 1979.

Tarka P., Specyfika i komplementarność badan ilościowych i jakościowych, «Wiadomości Statystyczne» 2017, vol. 3.

Thiem A., Duşa A., QCA: A Package for Qualitative Comparative Analysis, «The R Journal » 2013, vol. 5 .

Wajzer M., Modele matematyczne w politologii - podstawy teoretyczne i przykłady użycia, «Studia Politologiczne» 2019, vol. 53.

Weber M., The Methodology of Social Sciences, New York 1949.

Zadeh L., Fuzzy Sets, «Information and Control»1965, No. 8.

Załęski P., Typy idealne w socjologii religii Maxa Webera. Analiza struktury kategoryzujacej pole religijne, «Kultura i Społeczeństwo» 2003, vol. 1. 